\title{
Ambivalentsuse poeetika
}

ANNELI SARO

Artiklis keskendutakse teatrikunsti kaheplaanilisusele ja sellest sündivale ambivalentsuse poeetikale. Artikkel on jagatud kolme ossa. Esimeses osas tutvustatakse teatrikunsti kaheplaanilise toimimise erinevaid käsitlusi, teises kaheplaanilisusest tekkivat ambivalentsuse poeetikat ning kolmandas osas toodud näited Teatri NO99 lavastustest demonstreerivad erinevaid ambivalentsuse allikaid.

Kuigi nimetatud fenomenide selgitamiseks kasutatakse artiklis peamiselt kirjandus- ja teatriteoreetilisi materjale, on ambivalentsuse poeetika rakendatav ka teistele kaunitele kunstidele (muusikale kui pigem mitterepresentatsioonilisele kunstiliigile siiski kõige vähem). Kuna empiirilised näited pärinevad teatrist, mis on rollimängu kaudu seotud mängude laia skaalaga, siis tõuseb üksikjuhtumite tagant esile kogu inimeste mängulise ja kultuurilise tegevuse ambivalentsus.

\section{Mängu ja kunsti kaheplaanilisus}

Mänguteooriates ja etendusuuringutes on kauneid kunste käsitletud mängude osana, seepärast nimetatakse ka selle artikli alguses kunste mänguks. Enamasti käsitletakse mängu argielule ja reaalsusele vastanduva mittetulusa tegevusena, mis pakub osavõtjatele lõbu. Sellele üldistusele vaatamata on mäng olemuselt kaheplaaniline: ühelt poolt on mäng sümboolne, teiselt poolt reaalne tegevus; ühelt poolt loob mäng autonoomse sfääri, kuid teiselt poolt matkib sotsiaalseid suhteid; ühelt poolt juhivad mängu reeglid, teiselt poolt võib neid reegleid kombineerida, tõlgendada, muuta või rikkuda; ühelt poolt juhib mängu lõbu kui asi iseeneses, teiselt poolt mõjutavad mängus tekkinud suhted, teadmised ja emotsioonid ning selle lõpptulemus - võit või kaotus - ka igapäevaelu. Isegi need, kes rõhutavad mängu ontoloogilise omadusena ebatõsidust või ebaproduktiivsust, on tunnistanud mängu transgressiivset potentsiaali, kasutades sõnu ja fraase, nagu mängu-tõsiduse mõiste (Huizinga 2004: 235), vastuoluline, mitmetähenduslik, ühekorraga mitmes eri suunas liikuv (Schechner 2002: 79), ambivalentne, dünaamiline ja olemuselt dialoogiline protsess (Schwind 1997: 427). Mängu kaheplaanilisust on käsitlenud paljud teoreetikud, kasutades selle nähtuse selgitamiseks enamasti binaarseid opositsioone ja dihhotoomiaid. Seda kinnitavad järgnevad kirjandus- ja teatriteooriate näited, mis toovad esile üksteisest mõnevõrra lahknevaid lähenemisviise. ${ }^{1}$

\footnotetext{
${ }^{1}$ Kuigi uurin ambivalentsuse poeetikat peamiselt etenduskunstide näidete põhjal, toon kahes esimeses teoreetilises peatükis näiteid ka kirjandusteadusest, pidades silmas nii ajakirja profiili kui ka asjaolu, et mängulisus ja teatraalsus kui kirjutamise ja kirjanduse implitsiitsed omadused on mind ammu huvitanud (vt Saro 2006, 2013).
} 
Näiteks Roland Barthes (2007: 73-75) eristab essees „Teksti mõnu” teksti figuratsiooni ja representatsiooni. Hasso Krull selgitab nende kahe termini erinevust just teatri näitel: „Figuratsioon erineb siis representatsioonist kõigepealt selle poolest, et ta on eelkõige ikkagi tegevus ise. Näiteks kui näitleja mängib laval Julius Caesarit, siis Caesarina on ta representatsioon (kangelane ise jääb igavesti puuduvaks), kuid tema tegelik näitlejatöö, liigutused ja miimika, kogu otsene kehaline väljendus kuulub figuratsiooni alla. See „ei puudu”, ei esinda midagi muud.” (Krull 1992: 30) Semiootiliselt väljendudes on figuratsioon keskne tekstiühik, mis alles representatsioonina muutub märgiks, täpsemalt tähistajaks. Kuid erinevalt semiootikast kui strukturalistlikust meetodist on Barthes'il meelel midagi enamat ja ebamäärasemat, sest ta nendib: „Figuratsioon on erootilise keha ilmnemise viis [---] tekstiprofiilis” (Barthes 2007: 73). Barthes'i järgi võib figuratsioon ilmneda tekstis autorikujundina, tegelasena või teksti enda kehana; figuratsioon tuleb esile siis, kui ta lükkab representatsiooni edasi või eemale. Seega, kuigi representatsioon ja figuratsioon on omavahel tihedalt seotud, esimene ilmneb ainult teise kaudu, siis nende suhted on mängulised ja varieeruvad ning nad mõlemad pürivad kohati autonoomsuse poole oma vastasmängijat teatud hetkil tõrjudes.

Barthes'ile mõnevõrra lähedane on teatriuurija Jean Alteri kontseptsioon etenduse referentsiaalsest ja performatiivsest (ingl performant) funktsioonist teoses „Teatri sotsiosemiootiline teooria” „[---] teatri tuum seisneb pidevas pinges tähendusi loovatele märkidele tugineva referentsiaalse funktsiooni ja selle vahel, mida ma nimetan performatiivseks funktsiooniks ja mis pole seotud semiootilise protsessiga, vaid rahuldab emotsionaalset vajadust olla tunnistajaks erilistele saavutustele: füüsilistele, esteetilistele, tehnilistele jne" (Alter 1990: 32). Kui referentsiaalne funktsioon langeb kokku representatsiooniga, siis performatiivse määratlemine on mõnevõrra keerulisem. Esiteks olen tõlkinud Alteri termini performant parema eestikeelse sõna puudumisel performatiivseks (performative), kuigi näiteks Cambridge'i sõnaraamat seostab esimest efektiivsuse ja teist mõjuga (CD: performant, performative), kuid neid samatüvelisi sõnu seob eesti keeles tõhususe mõiste. Kultuuriteoorias ongi performatiivsuse mõiste levinud kahes tähenduses: ühelt poolt J. L. Austinist ja performatiivist kui teatud kõneteost lähtudes mõju ja tõhususe tähenduses ning teiselt poolt etenduskunstidest ja etendusest (ingl performance) lähtudes etenduslikkuse tähenduses. Kuigi siin on tegemist ühe mõiste hargnenud tähendusväljadega, siis teater nagu kunstid üldiseltki kasutab oma mõju suurendamiseks performatiivseid väljendusvahendeid. Alteri performatiivset funktsiooni ei saa siiski taandada ainult teose väljenduslikuks, vormiliseks pooleks, sest ta rõhutab, et performatiivsus tuleb esile just eriliste füüsiliste, esteetiliste, tehniliste jms saavutuste kaudu. Seega performatiivne funktsioon domineerib referentsiaalse üle vaid teatud (tüüpi) teostes. Tähelepanu tuleb pöörata sellelegi, et Alter seob esitusega ka vastuvõtu ja emotsionaalse mõju, ühendades nii performatiivsuse mõlemad tähendusväljad.

Kui eeltoodud dihhotoomiad olid pigem universaalsed, st on rakendatavad kunstile üldiselt, siis Elizabeth Burns ehitab oma teatriteooria üles publiku vastuvõttu suunavatele kahte tüüpi konventsioonidele: retoorilistele (etendajate ja vaatajate vaheline kommunikatsioon) ja autentivatele (ingl authenticating, tegelastevaheline 
kommunikatsioon) (Burns 1972: 31). Retoorika all peab Burns silmas nii verbaalseid kui ka mitteverbaalseid väljendusvahendeid ning retooriliste konventsioonidega tähistab ta nii mingi konkreetse ajastu teatritegemise tavasid üldiselt kui ka konkreetse žanri või lavastusega seotud tinglikke kokkuleppeid. „Näitlejate ja vaatajate vahel on implitsiitne leping, et näitlejatel lubatakse esile manada fiktsionaalne maailm, et nende tegevused ja sõnad on tähenduslikud ja afektiivsed (mitte instrumentaalsed ega efektiivsed) koha, aja, situatsiooni ja tegelase juhuslikult määratud seostes" (Burns 1972: 31). Autentivad konventsioonid viitavad aga sellele, et teatrimängu tekst ja tegevus tuginevad mänguvälistele, ajastuomastele väärtussüsteemidele ja käitumisnormidele, mis loovad tervikliku, sidusa ja usutava maailma mulje (Burns 1972: 32). Niisiis ühelt poolt kehtestavad teatritegijad igal õhtul publikuga teatud mängureeglid, kuid teiselt poolt püüavad nad publikut veenda neid reegleid unustama. Tegemist pole ainult või lihtsalt mänguga, vaid teatritegijate kunstilise tõlgendusega mingist imaginaarsest või reaalsest maailmast, sh nende sotsiaalse kommentaariga kujutatavale. Kuid Burns näitab, et see pole kestev dihhotoomia, vaid eri ajastutel ja eri vooludes kipub neist konventsioonidest üks domineerima. Retooriliste konventsioonidena nimetab ta näiteks proloogi, epiloogi, monoloogi, kõrvalerääkimist, publiku poole pöördumist ja teater teatris võtet (populaarne renessanssdraamas, sh Shakespeare'il, kuid ka hiljem modernistlikes teostes), võõritavat näitlemist ja lavakujundust (näiteks eepilises teatris), kuid ka tinglikku või tühja lava jms. Autentivad konventsioonid pääsevad enim mõjule realistlikus draamas, kuid seegi on kõigest teater oma eriliste retooriliste konventsioonidega (näiteks tegevuse kontsentreeritus, publiku informeerimine olulistest mineviku- või olevikusündmustest, eneseavamine usaldusisikule, tihendatud fiktsionaalne aeg, kujundiloome jms). (Burns 1972: 40-97) Probleem on aga selles, et kui retoorilised ehk teisisõnu performatiivsed konventsioonid on pigem teatrispetsiifilised ja võivad teatrikaugele vaatajale mõjuda võõritavalt ja seega küsitavalt, siis kehtivatele sotsiaalsetele konventsioonidele tuginevad võtted mõjuvad autentselt, usutavalt - esindavad Elutõde, nagu Stanislavski märgib (2017: 366) - ning enamasti ei tekita küsitavusi, vaid pigem kinnitavad olemasolevaid konventsioone. Retoorilised konventsioonid suunavad seega etendust vaatama teatrina, autentivad konventsioonid aga reaalse maailmana. Lavastust, kus läbivalt domineerivad retoorilised konventsioonid, on võimalik ette kujutada (näiteks abstraktne, mitterepresentatiivne tants või performance), kuid vastupidist, kus autentivad konventsioonid tõrjuvad välja kõik kunstile viitavad märgid ning domineerib puhas representatsioon, üsna keeruline. Enamasti töötavad need konventsioonid siiski koos. Samas retseptsiooniprotsessis on kaldumine ühte või teise äärmusesse võimalik.

Kui Burns läheneb teatrile suuresti dramaturgiapõhiselt ning rõhutab teatri paiknemist teatud ajastu-, žanri- või stiilikonventsioonide ja elulise reaalsuse vahealas, siis Luule Epner loobub viimasest ning võtab kasutusele hoopis mõiste fiktsionaalne maailm, mis teatris on loodud suuresti mängu kaudu (2018: 57). Epner rõhutab, et maailm ja mäng ei välista teineteist, vaid põimuvad ja osaliselt kattuvad (2018: 11-12). Seega võib öelda, et mäng on tegevus ja maailm on tulemus. 
Laias laastus tähistavad Alteri performatiivne funktsioon, Burnsi retooriline konventsioon ja Epneri mäng sama asja: näitlejate, etendajate või laiemalt teatritegijate suhtlust publikuga spetsiifilises teatrikeeles. Semiootilises keeles tegelevad need etenduse aspektid tähistajaga, kuid ka kommunikatsiooni mittesemiootiliste aspektidega, nagu esteetika, energia, atmosfäär jms.

Kuna teater ja mäng liiguvad pidevalt fiktsionaalsuse-reaalsuse skaalal ja pingeväljas, siis on Epner võtnud oma teoorias aluseks esimese, fiktsionaalsuse ning Burns teise, reaalsuse, kui räägib autentivatest konventsioonidest. Alteri referentsiaalne funktsioon rõhutabki ju vaid seda, et tähistajad viitavad millelegi, mida laval pole, kuid see puuduolev võib kuuluda nii fiktsionaalsesse kui ka reaalsesse maailma. Tegelikult tuleb teatris eristada kahte reaalsust: etendajate ja vaatajate vahelise mängu reaalsust ning etendusevälist reaalsust. Kuigi representatiivse teatri kõrval on muutunud järjest domineerivamaks ka mitterepresentatiivne teater (vt nt Saro 2014), mille keskmes on performatiivne funktsioon ja olemasoleva, mitte puuduva esitlus, siis on selliseski etenduses referentsiaalne funktsioon esindatud, näiteks etendusesiseste viitesuhete kaudu, aga ka viidetena teatrivälisele reaalsusele või teatridiskursusele. Seega referentsiaalsuse mõiste on piisavalt avar, et seda mitte taandada ainult fiktsionaalsetele representatsioonidele, vaid seda saab kasutada ka reaalsuse representatsioonide puhul.

Epner kasutabki paralleelselt fiktsionaalse maailmaga mõistet võimalik maailm. See tundub nüüdisteatri teooria loomisel eriti sobilik, sest võimaldab endasse haarata fiktsionaalse-reaalse skaala mõlemad otsad ja hübriidsed vahevormidki. Nimelt ei kehtestata nüüdisteatris alati fiktsionaalseid maailmu, vaid kujutatakse ka reaalseid või inimeste sisemaailmu, mis võivad olla küll subjektiivsed või poolfiktsionaalsed, kuid lavale toodud ometi reaalsuse esitlemise kavatsustega (näiteks loeng-etendus, dokumentaalteater või nn argieluekspertide teater, kus tavalised inimesed jutustavad oma lugusid). Kui teatrilaval esitatu polegi alati fiktsionaalne või püüab oma fiktsionaalsust varjata teatud retoorilisi võtteid kasutades, siis võimaliku maailma mõiste ei takerdu autentsuse küsimusse, vaid aktsepteerib kõiki maailmu võimalikena ja sedakaudu usutavatena. Ning kui mängu ei käsitleta kitsalt näitlemise või teise, fiktsionaalse reaalsuse loomise tähenduses, siis võib seda antud juhul mõista teatud tüüpi vormilise võttena, lavastuse poeetikana või üldisemalt teatriraamina, mis muudab kõik endasse sattuva mänguks. Kuna lava ei ole enam ammu teatrit piiritlev raam, siis määrab just mängupoeetika kindlaks nii teatrisündmuse sisu kui ka piirid ning kujuteldava maailma/olukorra sisemise loogika ja suhte mänguvälise reaalsusega, aga ka vastuvõtustrateegiad.

Kuigi mängu ja teatri kaheplaanilisust on käsitlenud paljud uurijad, on vähe tähelepanu pööratud sellele, kuidas on seda dihhotoomiat kui poeetilist võtet ära kasutatud nüüdisaegsetes etenduskunstides tähenduste, afektide ja mõju loomisel. 


\section{Ambivalentsus ja poeetika}

Artikli järgmises osas keskendun mängu kaheplaanilisusest tekkivale ambivalentsusele kui poeetilisele ja retseptsiooniesteetilisele fenomenile, mida selgitan teatri näitel. Merriam-Websteri sõnaraamat annab sõnale ambivalence kaks tähendust: 1) üheaegsed ja vastuolulised suhtumised või tunded objekti, isiku või tegevuse suhtes; $2 \mathrm{a}$ ) pidev kõikumine (ühe asja ja tema vastandi vahel), $2 \mathrm{~b}$ ) ebakindlus, millise lähenemise vahel valida (MWD: ambivalence). Mõlemad tähendusväljad on siinse artikli kontekstis olulised, sest toovad esile nii spetsiifilise hoiaku/tunde kui ka sellega seotud dünaamika: ühelt poolt aktiivsuse, kõikumise kui tegevuse ja teiselt poolt inertsuse, suutmatuse otsustada. TEA entsüklopeedia selgitab ambivalentsuse terminit kirjanduse ja psühholoogia kontekstis. Nenditakse, et kunstiline tekst on juba olemuselt mitmetähenduslik ning et „[s]elgelt ambivalentsed on mõned kirjandusvormid (allegooria, valm, parabool) ja kujundid (iroonia, metafoor, metonüümia, oksüümoron, paradoks)". Psühholoogias pärineb see termin psühhoanalüüsist ja seda on peetud üheks skisofreenia nähuks, intellektuaalne ambivalentsus seisneb aga suutmatuses otsustada. (TEA: ambivalentsus)

Kui seni tutvustatud teooriad on konstrueeritud suuresti kunstiteosest lähtudes, siis järgnevad käsitlused püüavad selgitada kunsti kaheplaanilist kommunikatsiooni vastuvõtja vaatepunktist. Kirjanduse kaheplaanilist olemust ja vastuvõttu selgitab hästi Arne Merilai kahe konteksti teooria. Nimelt käsitleb ta kõnetegusid kahel kontekstitasandil: „Kitsas keelelis-semantilises alas tõlgendatakse lausungi tähendust võimalike maailmade taustal üldiselt, laias semantilis-pragmaatilises ruumis aga konkretiseeritakse tähendus vastavalt tegelikkusele" (Merilai 2003: 16). Merilai usub, et liikumine kahe konteksti - mängult uskumise ja fiktsioonist eemaldumise - vahel toimub spontaanselt ning et kontekstid võivad üksteises peegelduda, näiteks kitsa konteksti tähendusi tõlgendatakse laia konteksti ehk tegelikkuse taustal. (Merilai 2003: 16, 161-163) Niisiis, kui teoreetiliselt võib kunstiteoses eristada erinevaid osiseid, funktsioone, konventsioone ja kontekste, siis retseptsiooniprotsessi analüüsides on seda oluliselt keerulisem teha, sest toimub pidev voogamine, peegeldumine ja sulandumine.

Bruce McConachie (2008: 42-55) on püüdnud etenduse kui kaheplaanilise nähtuse vastuvõttu täpsemalt eritleda, tuginedes viimasel paarikümnel aastal teatriuurimises mõjukale neuroteadusele. Ta laenab Gilles Fauconnier'lt ja Mark Turnerilt mõiste kontseptuaalne põiming (ingl conceptual blending), et seletada, kuidas vaatajad suudavad oma tajus kokku siduda etenduse performatiivse ja referentsiaalse funktsiooni ehk luua selliseid põiminguid nagu näitleja/tegelane või objekt/fiktsionaalne ese. Fauconnier' ja Turneri arvates omandavad inimesed kontseptuaalse põimingu tehnika juba lapsepõlves ja hiljem kasutatakse seda automaatselt komplekssete kognitiivsete kontseptsioonide loomiseks allpool teadvuse taset. (Fauconnier, Turner 2002: 179-180, 266-267) Näitleja/tegelase põiming koosneb vastavalt neljast

\footnotetext{
${ }^{2}$ Eesti keelde tõlgitud varem ka kui segu või suland, kuid antud juhul pole tegemist mängu ja reaalsuse täieliku segunemise või sulandumisega, kus vaataja ei suuda näitlejat tegelasest eristada, vaid pigem paralleelsusega, kus toimub hetkelisi kokkulangemisi või ühe tasandi taandumisi.
} 
komponendist: 1) üldmõiste ehk antud juhul identiteedi kontseptsioon, 2) näitlejat puudutav info, 3) tegelast puudutav info ja 4) põiming. Kusjuures esimene neist on tugevalt seotud mäluga, st inimese varasema kultuurikogemusega. Näitleja/ tegelase põiming sõltub suuresti näitleja tuntusest ning lavastuse poeetikast. Näiteks teleseriaalidest, filmidest ja reklaamidest tuntud või pika lavastaažiga näitlejate puhul kipub põimingus näitleja domineerima tegelase üle. Nüüdisteatris kasutatakse harva näitleja identiteeti varjavaid võtteid, nagu parukas ja tugev grimm või hääle moonutamine, pealegi ei pruugi lavastuses selgelt identifitseeritavaid tegelasi olla. McConachie (2008: 50) usubki, et mängu jõud peitub just nimelt selliste põimingute ambivalentsete komponentide koostoimes: vaataja suudab elada selles põimingus, kuid on võimeline vajadusel ka reaalsusega silmitsi seisma.

Ambivalentsuse poeetika põhineb nii teose loomisel kui ka vastuvõtul tekkival mitmetähenduslikkusel. Nüüdisteatris tekitavad ambivalentseid tähendusi ja tundeid järgmised aspektid:

- üheaegselt fiktsioonile (teater) ja reaalsusele (ühiskond) viitavad märgid;

- etendaja identiteet (tegelane-etendaja-meedium-kodanik);

- väljenduslaad (tõsine versus mänguline, traagiline/vihane versus koomiline/irooni-

line, traditsiooniline versus uuenduslik);

- teatritegijate kavatsused ja ideoloogiad (meelelahutus versus esteetiline/didaktiline/poliitiline projekt).

Teatri intentsionaalsed strateegiad mängida samaaegselt sümboolsel ja mittesümboolsel tasandil toovad esiplaanile mängu ja teatri ontoloogilise ambivalentsuse ja põhjustavad retseptsiooniprotsessis nii tähenduslikku kui ka afektiivset ambivalentsust. Sellised esteetilised ja kommunikatiivsed strateegiad loovad koostoimes ambivalentsuse poeetika, kus kunsti mänguline ja performatiivne aspekt põimuvad ehk vastuvõtjat püütakse mõjutada mängu kui olemuslikult kaheplaanilise olukorra ja tegevuse kaudu. Kuigi teater on juba ontoloogiliselt kaheplaaniline, siis teatud teatrivormid pigem varjavad ja teised jälle rõhutavad seda. Näiteks realistlik teater, mis kujundab populaarset maitset ja arusaama teatrist, kaldub oma retoorilisi konventsioone ja performatiivseid praktikaid varjama, luues mulje nullstiilist ning seades esiplaanile illusiooniloome ja referentsiaalse funktsiooni. Samal ajal eksponeerivad realismieelsed ja -vastased kunstivoolud, aga ka muusika- ja tantsuteater nii oma referentsiaalset kui ka performatiivset funktsiooni. Kuid küsimus pole ainult teatriraami (fiktsiooni ja reaalsuse vastasseisu) või retooriliste vormikonventsioonide (realistlik versus ebarealistlik võttestik), vaid ka tähendusloome või meeleolu ambivalentsuses. Näiteks performatiivsuse esteetika strateegiad võivad luua ambivalentseid sõlmi, kui vastandlikud informatsioonivood, kõneviisid või meeleolud põimuvad omavahel, juhtugu see plaanitult või juhuslikult. Mäng erinevate kunstiliikide (eriti teatri ja tegevuskunsti), aga ka teatriliikide (sõna- ja tantsuteatri) ja žanride (draama ja komöödia) piiril või teatri traditsiooniliste piiride ületamine (püstijalakomöödias, poliitilises või osavõtuteatris jne) on samuti levinud ambivalentsuse poeetika strateegiad. 
Järgnevalt keskendun ambivalentsuse poeetika vastuvõtule ja tulen tagasi nn põimingu fenomeni juurde. Näiteks Erika Fischer-Lichte rõhutab kunsti kaheplaanilisuses hoopis dünaamilisust: vastuvõtja taju multistabiilsust ehk tajurežiimide pidevat vaheldumist kohalolu ja representatsiooni või teisisõnu performatiivsuse ja referentsiaalsuse vahel. Üleminekul ühest tajurežiimist teise tekib aga liminaalne seisund, mida Fischer-Lichte nimetab läveks. Lävi on väga ambivalentne ning seal võib aset leida vastuvõtja transformatsioon, mis põhjustab kehas füsioloogilisi, afektiivseid, energeetilisi ja motoorseid muutusi. (Fischer-Lichte 2008: 147-148, 174, 205)

Ambivalentsus on mängu ja teatri olemuslik komponent, mis võib muuta vastuvõtja esteetilist ja sotsiaalset taju. Helena Grehan on kommenteerinud ambivalentsuse potentsiaali kommunikatsiooniprotsessis:

Selle asemel et pidada ambivalentsust millekski, mis viib seisaku ja inertsini, peaks selle ümber mõtestama muutusi esile kutsuvaks ja produktiivseks loovaks ruumiks. Ambivalentsus ega otsustamatus ei viita tingimata sellele, et subjekti haarab segadus või halvatus tähenduse loomisel [---]; pigem võib see tekitada keskkonna, kus subjektid saavad teadlikuks oma reageerimiskohustusest, aga ka sellest, et iga nende reaktsioon on loomult ebapüsiv või ebakindel. (Grehan 2009: 34-35)

Seega teravdab ambivalentsus kui fenomen kriitilist tähelepanu info loomise ja vastuvõtu strateegiate suhtes ning õhutab maailma teisiti kujutlema ja ümber kujundama.

Kuid plaanitud strateegiad ei realiseeru alati retseptsiooniprotsessis. Poola lavastaja Jerzy Grotowski on analüüsinud artiklis „Teater ja rituaal” oma katsetusi ambivalentsuse poeetikaga, mida ta kriitik Tadeusz Kudliński eeskujul nimetab naeruvääristamise ja apoteoosi dialektikaks. Grotowski toob näiteks teosed, mille struktuuris peitus traagilise alatooniga iroonia, nagu Juliusz Słowacki draama „Kordian” ja Adam Mickiewiczi „Peiede” lavastused 13 Rea Teater-Laboratooriumis 1960. aastate esimesel poolel. Kuid see dialektika ei toiminud vajaliku täpsusega, sest mõned vaatajad võtsid selle vastu kui apoteoosi ja teised kui naeruvääristamise. Muidugi leidus ka vaatajaid, kes jõudsid mõlema aspekti tunnetamiseni ja „reageerisid dialektikale mainimisväärse stiihilisusega, mis polnud mängitud, vaid tõeline, sügavast sisimast tulev" (Grotowski 2002: 82). Kuid see siiski ei rahuldanud Grotowskit, sest ta eristas ka dialektika mõjus kahte eraldiseisvat kihti: „[---] vahetus reageeringus, kui vaataja oli lummatud, avaldas mõju apoteoosi aspekt, aga mõtlemise puhul mõjus naeruvääristamine" (Grotowski 2002: 82). Leides, et dialektika mõju ühtsus ja publiku kogukondlik ühtsus ei ole saavutatav, loobus ta rituaalsest teatrist.

\section{Ambivalentsuse poeetika Teatri NO99 lavastuste näitel}

Teatri NO99 lavastustes prooviti tihti luua piiridel mängimisest sündivat ambivalentsust, sest kombineeriti erinevaid performatiivseid strateegiaid. Artikli kolmandas osas toongi näiteid Teatri NO99 erinevat tüüpi ambivalentsuse poeetikatest: 
„NO75 Ühtne Eesti suurkogu” (2010) balansseeris teatri ja mitteteatri, täpsemalt poliitika vahealal, „NO33 Hüsteeria” (2017) vastandas teatri ja tegevuskunsti esteetika ehk representatsiooni ja presentatsiooni ning „NO88 ГЭП ehk Garjatšije estonskije parni" (2007) liikus rahvusliku propaganda (dramaatiline) ning selle paroodia (koomiline) vahealal.

„NO75 Ühtne Eesti suurkogu” (2010, idee ja kontseptsiooni autorid ning lavastajad Tiit Ojasoo ja Ene-Liis Semper), 44 päeva kestnud projekt algas 24. märtsil 2010 Tallinna kesklinnas välireklaamiga, kus Teatri NO99 näitlejad reklaamisid hiiglaslikel plakatitel uut poliitilist liikumist Ühtne Eesti, täpsemalt selle suurkogu, mis pidi toimuma 7. mail Saku Suurhallis. Ühelt poolt hõivas see kampaania suured kallid reklaamipinnad, eksponeeris ühes stiilis pintsaklipsustatud isikute arvutis töödeldud portreesid, sinimustvalge lipuke põsel, vaheldumisi populistlike loosungitega - võtted, mis kuuluvad (Eesti) poliitilisse diskursusesse ja parteide stiiliraamatutesse. Teiselt poolt kasutavad ka teatrid välireklaami, millel sagedasti eksponeeritakse peategelast mängivat näitlejat, ning selle kampaania fotodel olid ju Teatri NO99 näitlejad. Näitlejate sotsiaalne positsioon on aga nende ameti tõttu ambivalentne: konteksti ja isikut tundmata ei pruugi teada, kas nad on parajasti rollis või mitte. Ambivalentsed olid ka liikumise nimi (Ühtne Eesti on parafraas Venemaa suurima partei nimest Ühtne Venemaa, mille esindusisik on olnud Vladimir Putin) ja loosungid (parafraas Dumas' musketäride hüüdlausest ehk „Üks kõigi, kõik Eesti eest!” mõjus individualismi väärtustavas ühiskonnas irooniliselt).

„NO75 Ühtne Eesti suurkogu” poeetikat tutvustas trupp samal päeval Radisson Blue hotellis toimunud pressikonverentsil. Tiit Ojasoo teatas, et pärast kaht ja poolt aastat kestnud uurimistööd on selge, et seda õõvastavat materjali ei saa kokku võtta tavalise lavastusega, vaid nad on otsustanud ellu kutsuda erakonna Ühtne Eesti. EneLiis Semperi väitel kasutas Ühtne Eesti kõigi suuremate parteide hästi tuntud populistlikke võtteid. Lõpetuseks nentis Ojasoo, et paljud olulised liikumised ja parteid on Eestis alguse saanud naljatamisi. „See „nali” - sellel on potentsiaali!” (Ühtne 2010)

Tõepoolest, kogu projekt balansseeris läbivalt ja läbimõeldult nalja, st mängu, ja poliitika piiril, andes pidevalt vastuolulisi retoorilisi signaale. Oluline oli seejuures mängukohtade, žanride ja eestkõnelejate valik. Projekt ei toimunud teatrimajas, mis oleks kindlasti esiplaanile tõstnud selle mängulise, mittetõsise loomuse, vaid linnaruumis, hotellis, meedias ja Saku Suurhallis. Kasutati peamisi poliitikas ekspluateeritud žanre, nagu väli-, tele-, raadio- ja sotsiaalmeediareklaamid, pressikonverents, lõputu arv intervjuusid, koduleht ja suurkogu. Suurkogul pidasid peale näitlejate kõne endine õiguskantsler Allar Jõks ja Europarlamendi saadik Indrek Tarand. Niisiis demonstreeris „NO75 Ühtne Eesti suurkogu” mängu ja reaalsuse, täpsemalt poliitika kavalat põimingut, mis tekitas ühiskonnas ambivalentseid tundeid (kas Eesti poliitikamaastik võibki olla selline?) ja ootusi (äkki luuaksegi uus erakond?). Kuigi suurem osa ühiskonnast ilmselt mõistis selle mängu poeetikat, siis sellel „naljal" tõesti oli transformatiivne mõju nii Eesti poliitilise diskursuse kui ka teatri kui kunstiliigi esteetilise mõju ja sotsiaalse rolli mõistmisele. Väite kinnituseks võib tuua ajakirjandusest hulganisti selleteemalisi artikleid ja viiteid (vt nt Tamm 2020; Vaarik 2020) kuni viimase ajani välja. Samal ajal pole tehtud uuringuid, et väita, nagu oleks 
„NO75 Ühtne Eesti suurkogu” poliitilist või esteetilist diskursust otseselt muutnud, kuid selgesuunalised eesmärgid kuuluvadki pigem agitpropi ja didaktilise teatri, mitte ambivalentsuse poeetika juurde.

„NO33 Hüsteeria” (2017, lavastaja Ene-Liis Semper) algab sellega, et kahe diivani ja kahe sirmi, ekraani, prožektorite ja kaameratega varustatud lavale tulevad teatraalsetesse, isegi vulgaarsevõitu roosades toonides kostüümidesse riietatud etendajad Rasmus Kaljujärv, Eva Koldits, Rea Lest, Jörgen Liik ja Marika Vaarik. Nad istuvad diivanitele ja ilma mingi nähtava põhjuseta puhkevad üksteise järel naerma ning see kollektiivne hüsteeriline naer kestab järjest umbes 40 minutit. Samal ajal laval palju midagi ei tehta: etendajad aelevad diivanil, joovad vett, lollitavad, vahetavad aeg-ajalt kostüüme ning kasutavad kaameraid kui peegleid enesevaatluseks ja -näitamiseks. Üle kõige on aga naer - füsioloogiline reaktsioon vastava helitaustaga ja selle visuaalne võimendus lava tagaseinas oleval ekraanil.

Ene-Liis Semper kasutab siin tegevuskunstist tuttavat taluvuskunsti (ingl endurance art) või kestvusetenduse (durational performance) strateegiat, mille kõige kuulsamad näited on seotud etenduskunstnik Marina Abramovićiga. Taluvuskunst paneb proovile nii etendajate füüsilised võimed kui ka vaatajate taluvuse, tõlgendusvõimest rääkimata. „Hüsteeria” publik ei naera kaasa, sest lavategevus ja naer muutuvad aegamööda õõvastavateks. Kogesin ise etenduse 28. minutil tugevat südamepööritust ja füüsilist vastikust ning kaalusin võimalust saalist lahkuda.

Tahaksin väita, et lavastuse esimesed 40 minutit esindavad mitterepresentatiivset teatrit, kus vaatajad on seatud silmitsi vaid lakkamatu hüsteerilise naeru ja iseenda füsioloogiliste reaktsioonidega ja kus performatiivne funktsioon varjutab referentsiaalse. Kuid seda siiski teha ei saa, sest etendajad kujutavad hüsteeriat, mitte ei vaevle pidurdamatu naeru käes, ning teatrilava kui meedium muudab kõik sinna asetatu paratamatult millegi representatsiooniks. Niisiis võib rääkida üldisemast lavapoeetikast, lava kui kunstilise raami autopoeetilisest võimest muuta raami asetatu või sinna sattuv kunstiks, sealhulgas allutada see mingitele tuntud vastuvõtustrateegiatele, keskendugu need siis näiteks representatsioonile või narratiivile. Antud lavastuses on aga tegemist küllaltki ambivalentse olukorraga, kus teatri traditsioonilised konventsioonid ja vastuvõtustrateegiad kuigi hästi ei toimi, samal ajal kui mingeid muid konventsioone kas ei teata või ei saa neid etendusele otseselt üle kanda. Luule ja Eero Epner (2020: 29) ongi Ene-Liis Semperi lavapoeetikat nimetanud hübriidseks, sest ta kasutab vaheldumisi teatri ja teiste etenduskunstide poeetilisi võtteid, ning etendajate lavalolekut ambivalentseks, sest selles on nii kohalolule kui ka representatsioonile viitavaid elemente.

Peale selle aktiveerivad „NO33 Hüsteeria” pealkiri ja kujutatav nähtus mitmeid tõlgenduskontekste, mis muudavad lavategevuse representatsiooniks. Hüsteeria on kultuurilooliselt laetud mõiste, mida kasutati psühhiaatrias just naiste ( $\mathrm{kr}$ hystera 'emakas') suurenenud tundlikkuse ja erutuvuse diagnoosina ning mille XX sajandil vahetasid aegamööda välja terminid ärevus ja depressioon. Piret Karro (2020) on analüüsinud, kuidas viimastel aastatel on Eesti meedias kõlanud väljaütlemistes seostatud hüsteeriat naistevastase vägivalla kriitikaga, tasalülitades nii seda diskursust kui ka kriitikuid. Ojasoo ja Semperi 2017. aasta septembris antud intervjuud 
(Luik 2018), kus Semper mainis ka antud lavastust, nimetab Karro murdepunktiks termini hüsteeria soodiskursusesse lülitamisel ning aasta lõpus esietendunud „Hüsteeriat" Semperi kommentaariks hiljutistele naistevastase vägivalla käsitlustele, kus puudutati muu hulgas ka tema elukaaslase pahategu. Kuna Semper on oma videotes loonud endast sotsiaalselt tundliku etenduskunstniku kuvandi, siis tekib Karro tõlgenduse ja Semperi avaliku kuvandi vahel tugev konflikt, ambivalentsus, mis intrigeerib küsima ja edasi uurima. Hüsteeria kui mitterepresentatiivne ja avatud kujund selles lavastuses kutsub aga vastuvõtjaid end tähendustega täitma, sest ambivalentne hämarus tekitab ebamugavust.

Kognitiivse ambivalentsuse tekitab ka lavastuse „NO88 ГЭП ehk Garjatšije estonskije parni" (2007, lavastaja Tiit Ojasoo) pealkiri, mis on vene keeles, justkui oleks see suunatud venekeelsele publikule, kuigi nii see ei ole. „Kuumad eesti poisid” ei ole muidugi eesti meeste või Teatri NO99 meesnäitlejate enesekohane lausung, vaid stereotüüpi kinnitav fraas, millega lähinaabrid osutavad eestlaste rahvuslikule omadusele - aeglusele. Iroonia poeetilise võttena ja rahvusluse teema ongi selle lavastuse kesksed elemendid, mille ühildamatus tekitab vähemalt rahvuslikult meelestatud vaatajais kognitiivse ja emotsionaalse ambivalentsuse.

„ГЭП” tegeleb referentsiaalsel tasandil Eesti demograafilise olukorraga - rahvastiku vananemise ja vähenemise kui probleemiga. Seega lavastuses kujutatav maailm on XXI sajandi Eesti. Autorid kasutavad selleks mitmeid autentivaid konventsioone. Kodulehe väitel põhineb lavastus näitlejate improvisatsioonidel, võrgutusõpikutel ja erinevate eestlastega toimunud kohtumisõhtute stenogrammidel (ГЭП) ehk siis vähemalt osaliselt dokumentaalsel materjalil. Tsiteeritakse ja ilmselt ka parafraseeritakse rahvastikuteadlast Kalev Katust ja poliitik Evelin Seppa. Teatri NO99 rühmatöömeetodil sündinud lavastustele omaselt kannavad tegelased näitlejate eesnimesid ning autentsust taotlevad stseenid kantakse ette pihtimuslikus laadis ja argiriietuses. Seega vähemalt kohati ja laias kontekstis pakub „ГЭП” vaatajale äratundmist ja ehk isegi samastumisvõimalust.

Nagu „NO93 Nafta! Ver 1.2” (2006, lavastajad ja autorid Ojasoo ja Semper), dokumentaalne kabaree naftaajastu lõppemisest, nii on ka „ГЭП” dokumentaalne utoopia, mis ühelt poolt püüab mudeldada võimalikke tulevikustsenaariume ning teiselt poolt teha seda mittedidaktilisel meelelahutuslikul viisil. „ГЭП-is” otsustavad tegelased (või ikkagi etendajad, st Teatri NO99 näitlejad?), et eesti keele ja kultuuri päästmiseks tuleb rohkem lapsi teha ning tulemuslikkuse nimel - mitme partneriga. „Moraalselt on nende tegu vastuvõtmatu, eetiliselt kahtlane, kuid eesmärki silmas pidades ainuõige" (ГЭП), tunnistatakse ka lavastuse kodulehel eetilist dilemmat ja ambivalentsust. Järele mõeldes polegi see plaan nii utoopiline, sest paljud on üle läinud kogukondlikule peremudelile, kärgperele, kus mitu peret hoolitsevad järglaste eest ühiselt. Pealegi, õilis eesmärk pühitseb abinõu.

Kuigi lavastus lõpeb peaaegu pateetiliselt (eesti mehed on Eesti pähe õppinud), esitletakse rahvuslikku diskursust kas kerge võõrituse või selge irooniaga. Järjepidevalt ühendatakse kõrge ja madal (ärkamisaegsed laulud Hando Runneli sõnadele ning ebatsensuurne maskuliinne kõnepruuk või kopulatsiooni markeerivad liigutused), vastandatakse isikuvabadust, soostereotüüpe ja rahvuslikkust (mida 
esindasid rahvariided ja -tantsud ning rahvalikud laulud) ning hüperboliseerides paljusid olukordi (võrgutamiskunstitund, peenisetreening, suudlemiskoolitus jt). Peamiselt tehaksegi nalja eesti mehe kui rahvusliku ja soostereotüübi lihtsameelsuse, sõjakuse ja pragmaatilisuse üle, nagu stseenis „Lähme teeme lapsi”, kus Jaak Prints kamandab laval ja saalis olevaid naisi temaga lapsi tegema, või kui meesrühma rahvatantsunumbrist kasvab välja pingeid vallandav kaklus. Samas tasakaalustavad seda rahvuslikku kabareed muusikanumbrite ja sketšide vahele pikitud eleegilised pihtimuslikud monoloogid ja dialoogid, mis ei lasknud lõpuni kaasa minna komöödia vastuvõtustrateegiaga.

„ГЭП” tekitas eetilist ja kognitiivset ambivalentsust (näiteks kahtlustusi marurahvusluses või ropendamise hukkamõistu) nii Eestis kui ka mitmel pool Euroopas (Epner 2008), eriti endise idabloki vaatajate hulgas (Tuch 2008: 28). Olin etendusel ise tunnistajaks, kuidas paljud vaatajad tajusid küll soostereotüüpe, aga mitte rahvusideoloogiat õonestavat irooniat, st kõike rahvuslikku võeti vastu kroonuliku hardusega, tõrjudes lavastuse ambivalentsuse poeetikat.

\section{Kokkuvõtteks}

Teater ja teised kaunid kunstid, nagu ka mäng üldiselt, on olemuselt kaheplaanilised tegevused: samal ajal nii reaalsed kui ka sümboolsed. Kaheplaanilisus on seega kunsti ontoloogiline omadus, mida mõned poeetikad varjavad ja teised rõhutavad. Varjamatu kaheplaaniline tegevus tekitab nii tähenduslikku kui ka afektiivset ambivalentsust, millel on suur transgressiivne potentsiaal. Kui vastandlikud informatsioonivood, kõne- ja kujutusviisid või meeleolud omavahel põimuvad, tekivad ambivalentsuse sõlmed, mis peaksid vastuvõtjas aktiveerima erinevad tõlgendus- ja analüüsistrateegiad. Ambivalentsuse sõlmed võivad olla teoses juhuslikud või üksikud, kuid kui ambivalentsus on teose peamine poeetiline võte ja juhtmõte, siis võib rääkida ambivalentsuse poeetikast. Mäng kunsti ja mittekunsti piiril, aga ka erinevate kunstiliikide või žanride piiril on vähemalt teatris levinud ambivalentsuse poeetika võtted.

Ambivalentsus nähtusena on muidugi kõikehõlmavam kui esteetiline või retooriline võte. Simone de Beauvoir kasutab seda terminit keskse eetilise kategooriana oma teoses "Ambivalentsuse eetika” ning nendib, et eksistentsialismi defineeriti algusest peale kui ambivalentsuse filosoofiat (de Beauvoir 1948: 4). Kui see on nii, et eksistents ise seab inimese ette pidevalt ambivalentseid tõdesid ja valikuid, siis on ootuspärane, et kunstist otsitakse sellele tasakaalu: draamadele õnnelikke lõppe, mõrvalugudele lahendusi, elulugudele narratiivset selgroogu, õiglast karistust pahalastele ja lunastust kannatajatele. Teisalt leidub ühiskonnas ja kunstnikkonnas alati neid, kes ei rahuldu lihtsate lahendustega või kelle jaoks on kõik liiga selge, mustvalge, ning nemad vajavad ka ambivalentsuse poeetikat. 
Artikli valmimist on toetanud Tartu Ülikool (rahvusteaduste baasfinantseerimise uurimistoetus PHVKU20933 „Mängupoeetikad kui kultuurikommunikatsiooni strateegiad") ja Euroopa Regionaalarengu Fond (Eesti-uuringute Tippkeskus, TK 145).

\section{VEEBIVARAD}

$C D$ = Cambridge Dictionary. https://dictionary.cambridge.org/

MWD = Merriam-Webster Dictionary. https://www.merriam-webster.com/

\section{KIRJANDUS}

Alter, Jean 1990. A Sociosemiotic Theory of Theatre. Philadelphia: University of Pennsylvania Press.

Barthes, Roland 2007. Tekstimõnu. (Prantsuse vaim.) Tlk Tanel Lepsoo. Tallinn: Varrak.

Burns, Elizabeth 1972. Theatricality. A Study of Convention in the Theatre and in Social Life. London: Longman.

de Beauvoir, Simone 1948. The Ethics of Ambiguity. New York: Citadel Press.

Epner, Eero 2008. Kuidas NO99 Euroopas põõsasse kuses. - Eesti Ekspress 11. VII.

Epner, Luule 2018. Mängitud maailmad. (Heuremata. Humanitaarteaduslikke monograafiaid.) Tallinn-Tartu: Tartu Ülikooli Kirjastus.

Epner, Luule; Epner, Eero 2020. Ene-Liis Semperi autorilavastuste hübriidne esteetika. Kunstiteaduslikke Uurimusi, kd 29, nr 1-2, lk 7-30.

Fauconnier, Gilles; Turner, Mark 2002. The Way We Think: Conceptual Blending and the Mind's Hidden Complexities. New York: Basic Books.

Fischer-Lichte, Erika 2008. The Transformative Power of Performance: A New Aesthetics. London-New York: Routledge.

Grehan, Helena 2009. Performance, Ethics and Spectatorship in a Global Age. Basingstoke: Palgrave Macmillan.

Grotowski, Jerzy 2002. Teater ja rituaal. - J. Grotowski, Tekstid aastatest 1965-1969. Tlk Hendrik Lindepuu. Tallinn: Eesti Teatriliit, lk 71-98.

Huizinga, Johan 2004. Mängiv inimene. Kultuuri mänguelemendi määratlemise katse. (Ajalugu. Sotsiaalteadused.) Tlk Mati Sirkel. Tallinn: Varrak.

Karro, Piret 2020. Mida me teeme, kui kasutame sõna „hüsteeria”. - Müürileht 16. III.

Krull, Hasso 1992. Poststrukturalistlikud meetodid kirjanduse käsitlemisel. 4. loeng. - Vikerkaar, nr 7, lk 30-32.

Luik, Hans H. 2018. Ojasoo ja Semper aasta tagasi: NO99 jätkab veel kuus-seitse aastat. - Eesti Ekspress 31. X.

McConachie, Bruce 2008. Engaging Audiences: A Cognitive Approach to Spectating in the Theatre. New York: Palgrave Macmillan.

Merilai, Arne 2003. Pragmapoeetika. Kahe konteksti teooria. (Studia litteraria Estonica 6.) Tartu: Tartu Ülikooli Kirjastus.

Saro, Anneli 2006. Kirjandus kui etendus. - Keel ja Kirjandus, nr 2, lk 89-103. 
Saro, Anneli 2013. Writing: Exploring the margins of playing and theatricality. - Playing Culture - Conventions and Extensions of Performance. Toim Vicki Ann Cremona, Rikard Hoogland, Gay Morris, Willmar Sauter. Amsterdam-New York: Rodopi, 1k 105-118.

Saro, Anneli 2014. Reaalsuse re/presenteerimise strateegiad etenduskunstides. - Methis. Studia humaniora Estonica, nr 14, lk 55-71.

Schechner, Richard 2002. Performance Studies. London-New York: Routledge.

Schwind, Klaus 1997. Theater im Spiel - Spiel im Theater. - Weimerer Beiträge, kd 43, nr 3, lk 419-443.

Stanislavski, Konstantin 2017. Näitleja töö rolliga. Materjale raamatu jaoks. Tlk Maiga Varik, Peeter Raudsepp. Tallinn: Eesti Muusika- ja Teatriakadeemia Lavakunstikool, Eesti Teatriliit.

Tamm, Marek 2020. Kas ja mis mõju avaldas „Ühtse Eesti suurkogu”? - Postimees 16. V. TEA = TEA Entsüklopeedia. Kd 2: Alžiir-Aruba. Tallinn: TEA Kirjastus, 2009.

Tuch, Boriss 2008. Toruni „Kontakt 2008”. Me olime kolmandad, kuid missuguses seltskonnas! - Teater. Muusika. Kino, nr 12, lk 28-35.

Vaarik, Daniel 2020. JUUBELILUGU! 10 aastat Ühtse Eesti suurkogust - etendus, mis ei tahtnud lõppeda. - Õhtuleht 8. V.

Ühtne 2010 = Ühtne Eesti pressikonverents 24. III, https://www.youtube.com/watch?v=30eHIPREIqo. (13. V 2020)

ГЭП = ГЭП ehk Garjatšije estonskije parni. Teater NO99 koduleht. https://no99.ee/lavastused/no88-gep-ehk-garjatsije-estonskije-parni. (5. VIII 2020)

Anneli Saro (snd 1968), PhD, Tartu Ülikooli kultuuriteaduste instituudi teatriteaduse professor (Ülikooli 16, 51014 Tartu), anneli.saro@ut.ee

\section{The poetics of ambivalence}

Keywords: poetics, ambivalence, game, performativity, Theatre NO99

The article investigates the double nature of arts and the related poetics of ambivalence. Similarly to other forms of play, arts are simultaneously operating at two levels: at the symbolic level of play and the non-symbolic level of reality. The intentional strategy of playing at these levels simultaneously causes ambivalence of meanings and affects and has a strong transgressive potential.

The article is divided into three parts. First, different approaches (Barthes, Alter, Burns, Epner) to the double nature of arts are introduced. In the second part, the term "ambivalence" and poetics based on the notion are tackled, especially in the framework of reception (Merilai, McConachie, Fischer-Lichte). Finally, three productions from the repertoire of the Theatre NO99 are analysed as examples of the poetics of ambivalence.

When adversative flows of information, expressions or moods cross or intertwine, intentionally or accidentally, ambivalent nodes are created that are supposed 
to activate different reception and interpretation strategies in the perceiver. When ambivalence is the main poetic means or idea of a work, it represents the poetics of ambivalence. One of the main strategies of the poetics of ambivalence in theatre is playing at the thresholds of different genres and types of theatre or different art forms or at the threshold of art and non-art. The productions of the NO99 offered different experiences of liminality, since they often operated at the threshold of several performative strategies.

Note that although most of the sources used in the article represent theatre and literary theory, the poetics of ambivalence is also characteristic of other art forms, of games and culture in general and even of existence as understood in existential philosophy.

Anneli Saro (b. 1968), PhD, University of Tartu, Institute of Cultural Research, Professor of Theatre Research (Ülikooli 16, 51014 Tartu), anneli.saro@ut.ee 